\title{
INVESTIGATION OF THE EFFECTS OF ELECTROMAGNETIC RADIATION FROM A CELL PHONE ANTENNA ON A HUMAN HEAD MODEL
}

\author{
I.A. Amer, ahmedd20666@gmail.com, \\ O.J.A. Abdalgabar, omer.jamal1986@gmail.com, \\ N.V.Vdovina,nadzh@yandex.ru \\ South Ural State University, Chelyabinsk, Russian Federation
}

\begin{abstract}
Each cell phone emits electromagnetic waves. This paper describes the interaction between the electromagnetic radiation, EMR (electrical field, magnetic field and far-field radiation pattern in linear and in decibels, $\mathrm{dB}$ ) and the human head in existence of the mobile phone which consists of three components (plastic casing, metal base antenna and metal washer). The study of the human head model under the influence of cell phone radiation is carried out using the program EM.CUBE. The results of these study showed the possibility of using this program to evaluate the interaction of electromagnetic radiation with biological objects.

Keywords: cell phone, electromagnetic radiation, human head model, far-field radiation pattern, electromagnetic interaction.
\end{abstract}

\section{Introduction}

In the modern world of international communication, absolutely everyone uses cell phones. Each cell phone emits the minimum amount of high-frequency electromagnetic energy. Its power flux density does not exceed $100 \mu \mathrm{W} / \mathrm{cm}^{2}$. This radiation has various effects on human health. Thermal effects can lead to organic damage to body cells. According to public opinion polls among mobile phone users, if they are talking on the phone for more than 20 minutes in a row, the earlobes begin to heat up - this is due to the heating of the blood due to the effect of microwave radiation from cell phones. More serious problems begin with pain in the ears, which can develop into tinnitus or a feeling of constant tinnitus, which ultimately can lead to hearing loss and ear tumors. In addition, the excessive use of cellular phones leads to drying out of the skin and tear fluid in the eyes, sleep disturbance, loss of attention, memory loss and even to the development of many cancers [1].

The degree of absorption by a human body of the radiation of a cellular phone may be depend on the characteristics of the cellular network, the characteristics of the smartphone and its antenna, the position of the antenna, and also the energy of the radiation from the handset [2]. The dielectric properties of the human body also affect the values of the specific absorption rate (SAR), SAR values display the radiated power from mobile smartphone absorbed by human body over a selected volume of $1 \mathrm{~g}$ or $10 \mathrm{~g}$ of body tissues, and it's measured in watt per kilogram (W/kg) [3]. Individual tissues of the human body with an increased water content in them also have higher SAR values. The increased water content in the tissues of the human body means that the tissues of the body have increased conductivity, which means they are more vulnerable, since they are able to absorb electromagnetic waves well. The values of the conductivity and permittivity depend on the frequency of irradiation [4]. Conductivity and dielectric permeability of tissues are constant values if the frequency of irradiation of tissues remains constant. For this reason, a change in the value of the operating frequency ultimately changed the conductivity and dielectric permeability of the tissues.

The purpose of the experiment was to calculate and display the electrical field and magnetic field caused by the electromagnetic radiation of the mobile phone, affecting the human head and various components of the mobile phone (plastic casing, metal base of the antenna and metal washer) in linear units and in $\mathrm{dB}$, also three-dimensional (3D) far-field radiation pattern using the EM.CUBE program. 


\section{Mobile Phone Model and Human Head Model}

The simulated mobile phone model with external antenna of monopole type is shown in Fig. 1, and designed with adjusted frequency of $900 \mathrm{MHz}$ with bandwidth of $600 \mathrm{MHz}$. The mobile phone model consists of three parts: Metal washer, Metal base of antenna and a plastic box.

The following parameters are used as input data, presented in Tables 1 and 2. The characteristics of the dielectric components of the cellular phone model used in this simulation are summarized in Table 1 $[5,6]$. The dielectric parameters of the human head model are shown in Table 2 [7].

Table 1

The dielectric parts of the mobile phone and the corresponding material parameters

\begin{tabular}{|l|c|c|}
\hline \multicolumn{1}{|c|}{ Parameter } & $\varepsilon_{r}$ & $\sigma(\mathrm{S} / \mathrm{m})$ \\
\hline Plastic Box & 2.2 & 0.000 \\
\hline Metal Base of Antenna & 2.5 & 0.003 \\
\hline Metal Washer & 3.5 & 0.002 \\
\hline
\end{tabular}

Table 2

The dielectric parameters of a human head model

\begin{tabular}{|l|c|c|}
\hline \multicolumn{1}{|c|}{ Parameter } & $\varepsilon_{r}$ & $\sigma(S / m)$ \\
\hline Human Head & 65 & 0.600 \\
\hline
\end{tabular}

Fig. 2 shows the realistic human head model with mobile phone.

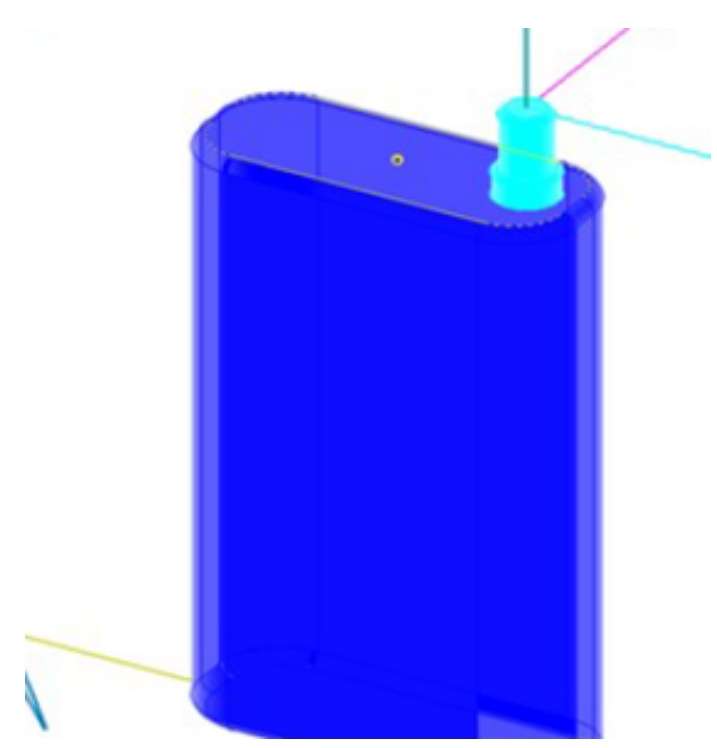

Fig. 1. The mobile phone used in simulation

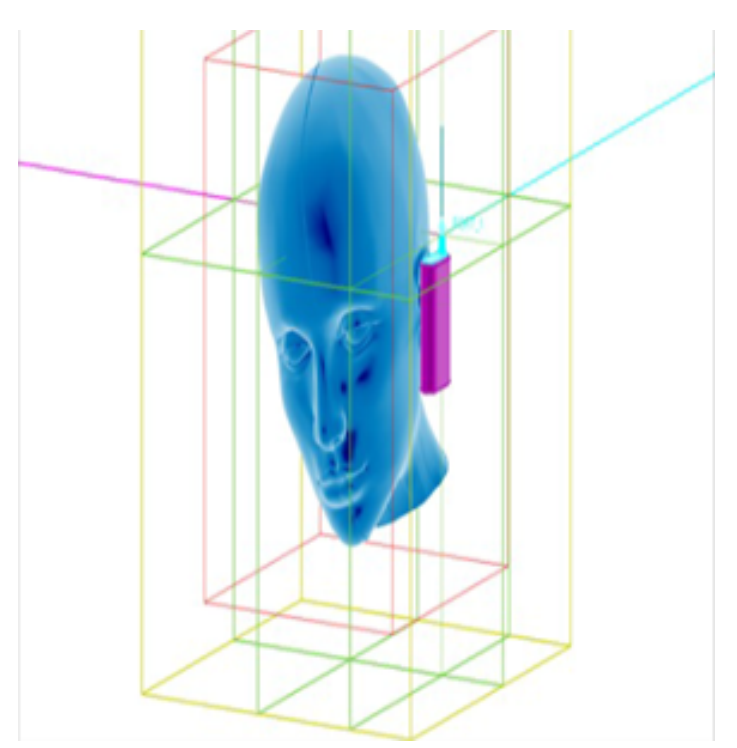

Fig. 2. The realistic human head model with mobile phone used in simulation

\section{Investigation of the interaction of electromagnetic radiation with models}

of a cell phone and a human head

By chosen the desired center frequency of $900 \mathrm{MHz}$ and a bandwidth of $600 \mathrm{MHz}$ for the mobile phone monopole antenna, it is necessary to enter into the program the dielectric permittivity $\left(\varepsilon_{r}\right)$ and conductivity $(\sigma)$ values for the human head and for various cell phone components from Tables 1 and 2. By importing the model of the human head model and mobile phone model from an external file (with the extension .STL), it is necessary to place the monopole antenna at the top of the metal box and defining all the excitations, boundaries, lumped source and assign far field radiation patterns. It is necessary to define four sensors one for human head and three for mobile phone components to observe the interaction between head and the mobile telephone.

The interaction parameters are calculated using the finite difference time domain method (FDTD). 
The effect of the total intensity of the influencing electrical field and the total intensity of the acting magnetic field in decibels $(\mathrm{dB})$ is shown in Fig. 3 for the sensor (1) at the human head (noticed that the maximum impact was observed in the immediate vicinity of the human head).
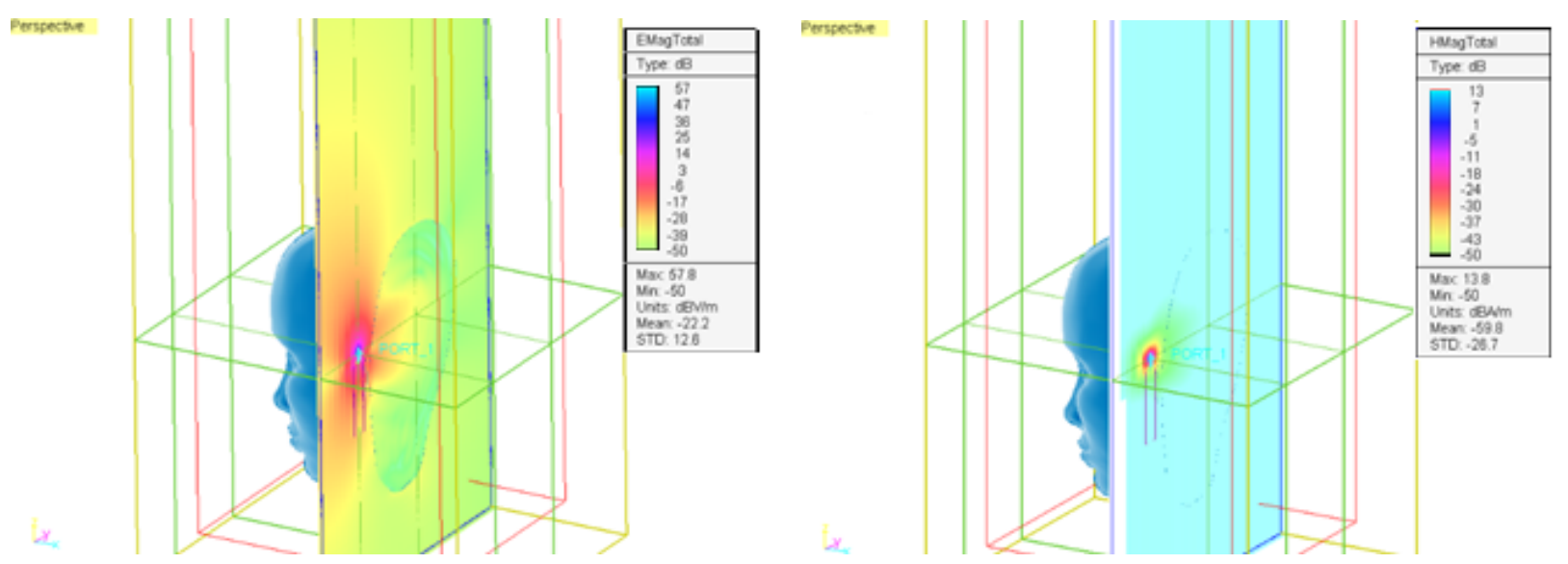

Fig. 3. Electrical field and magnetic field interaction with a human head, $\mathrm{dB}$

In Fig. 4-6 show the results of the interaction between the electrical and magnetic fields for the plastic box (sensor 2), the metal base of the antenna (sensor 3), and the metal washer (sensor 4), respectively.
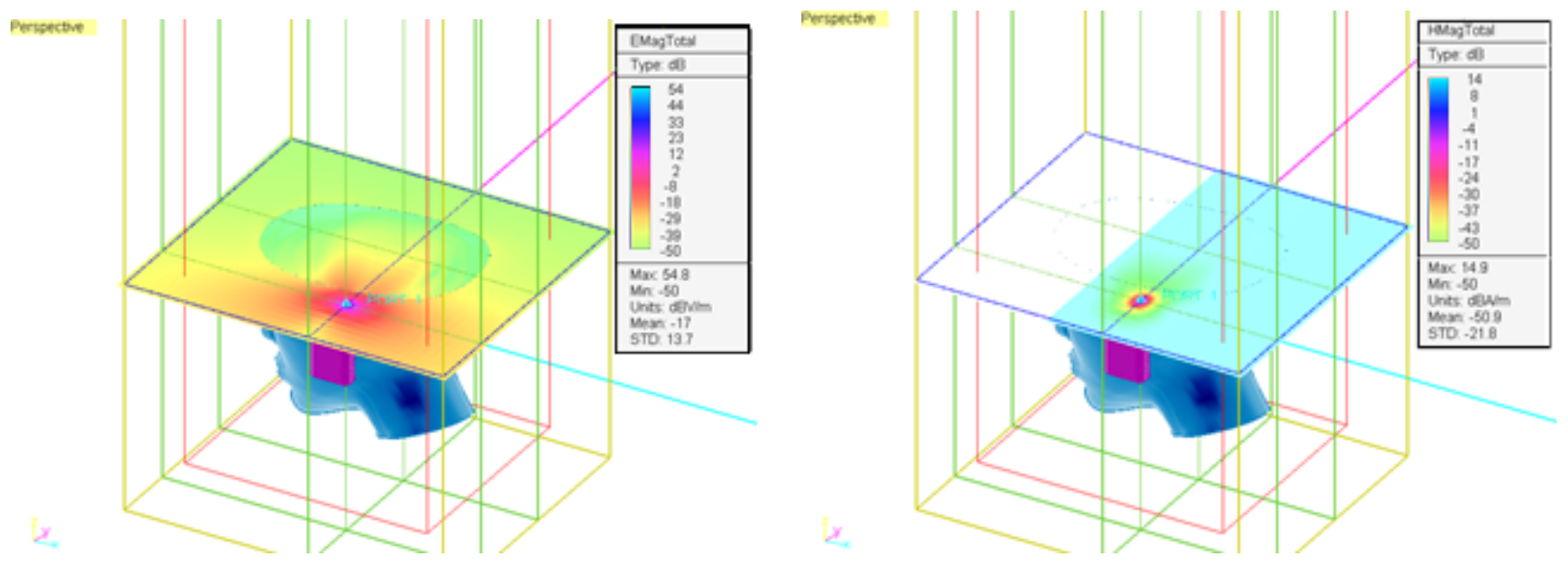

Fig. 4. Electrical field and magnetic field interaction with a Plastic box, dB
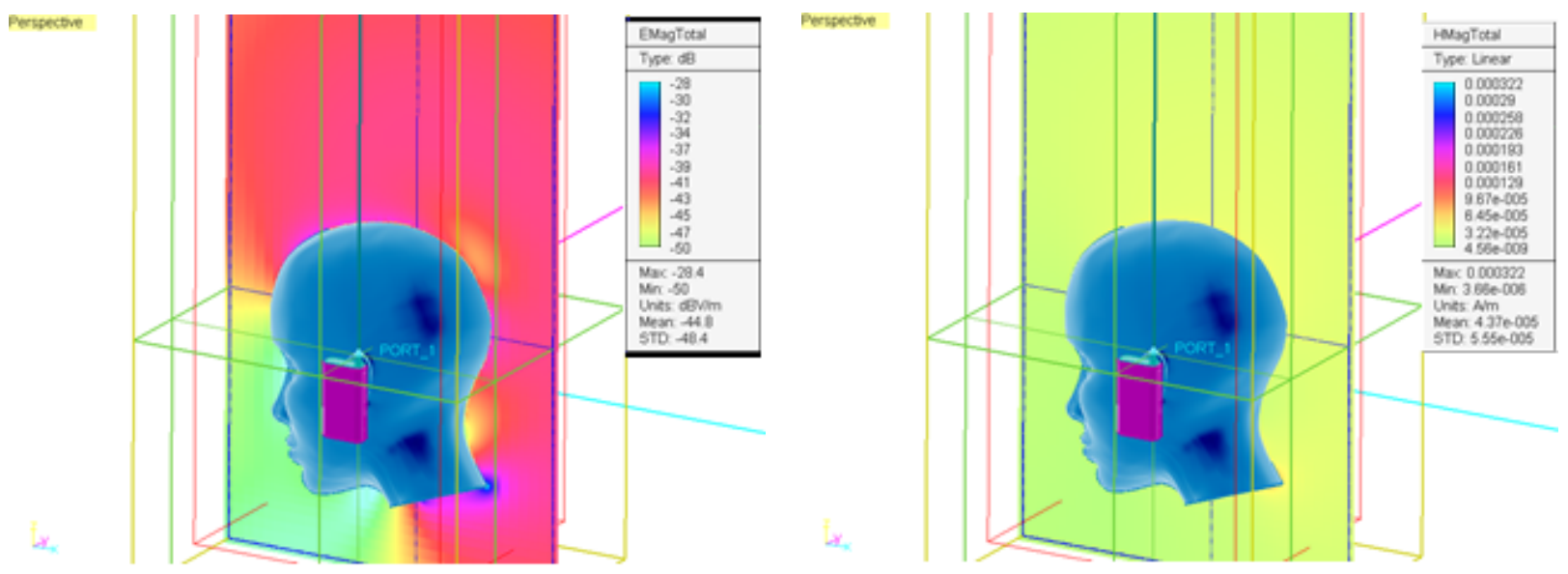

Fig. 5. Electrical field and magnetic field interaction with a metal base of antenna in linear and in $\mathrm{dB}$ 

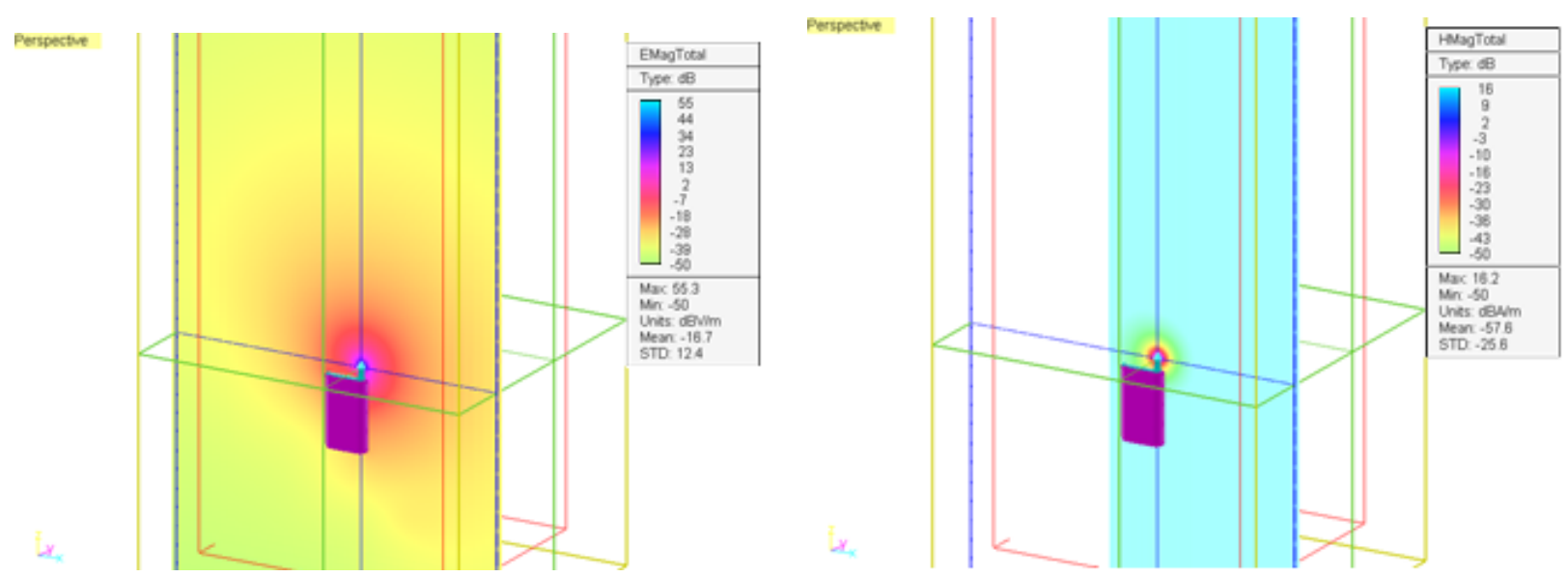

Fig. 6. Electrical field and magnetic field interaction with a metal washer, dB

\section{Results and Discussions}

Table 3 lists the maximum, minimum, average and standard values for the electrical and magnetic fields that were obtained as a result of the simulation. Notice that the maximum value for the electrical field $(57.8 \mathrm{~dB})$ is near the human head.

The resulting values of electrical and magnetic fields

Table 3

\begin{tabular}{|l|c|c|c|c|c|c|c|c|}
\hline \multirow{2}{*}{\multicolumn{1}{|c|}{ Parameter }} & \multicolumn{4}{|c|}{ Electrical Field, dB } & \multicolumn{4}{c|}{ Magnetic Field, dB } \\
\cline { 2 - 9 } & Max & Min & Mean & STD & Max & Min & Mean & STD \\
\hline Human Head & 57.8 & -50 & -22.2 & 12.6 & 13.8 & -50 & -59.8 & -26.7 \\
\hline Plastic Box & 54.8 & -50 & -17 & 13.7 & 14.9 & -50 & -50.8 & -21.8 \\
\hline Metal Base of Antenna & -28.4 & -50 & -44.8 & -48.4 & $\sim 0$ & $\sim 0$ & $\sim 0$ & $\sim 0$ \\
\hline Metal Washer & 55.3 & -50 & -16.7 & 12.4 & 16.2 & -50 & -57.6 & -25.6 \\
\hline
\end{tabular}

A three-dimensional (3D) diagram of far field radiation pattern (FF) from various angles is shown in Fig. 7. Notice that the use of the human head model made a far-field radiation pattern of the antenna extremely directional (Dir. $=2.479)$.

A two-dimensional (2D) polar radiation pattern in the $\mathrm{YZ}$ projection is shown in Fig. 8. It is necessary to set parameter S11 for the antenna in the electromagnetic field grid. Notice from Fig. 9, the return loss is minimized around $835 \mathrm{MHz}$.
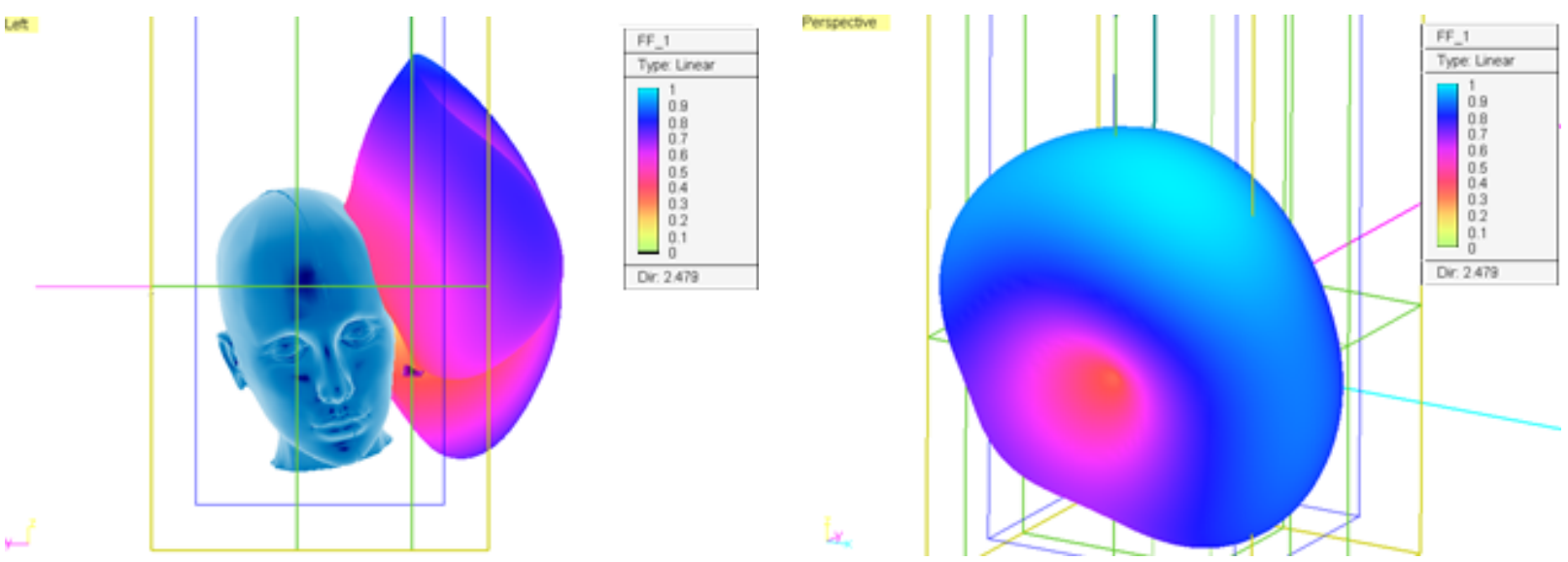

Fig. 7. 3D far field radiation pattern (FF)

(see also p. 167) 
Амер И.А., Абдалгабар А.О.Дж., Вдовина Н.В.

Top

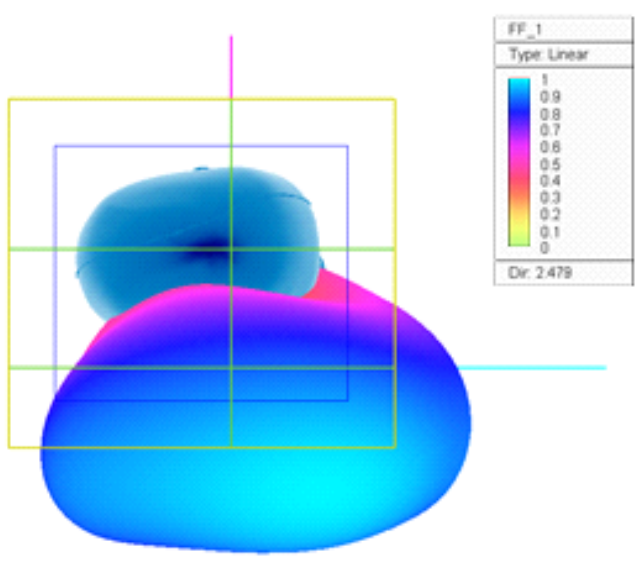

Исследование воздействия электромагнитного излучения сотового телефона на модель головы человека

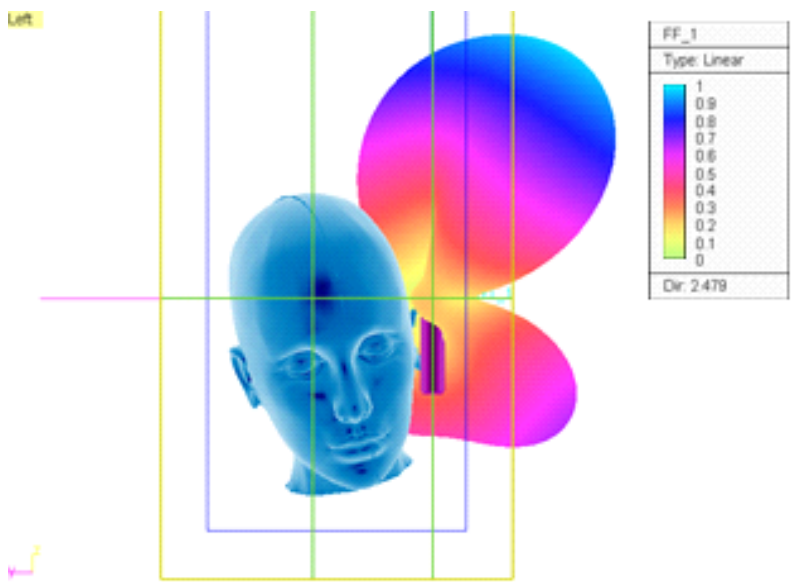

Fig. 7. 3D far field radiation pattern (FF)

(End)

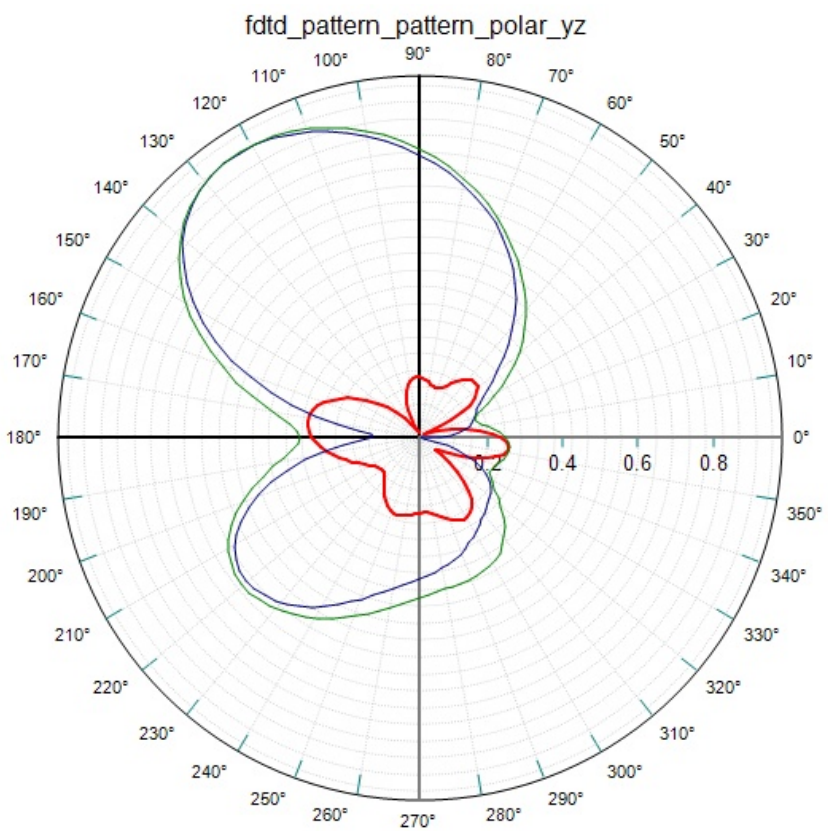

$\sqrt{\sqrt{\nabla}-\text { mag_e}_{-} \text {theta }}$

$\sqrt{\nabla}$ - mag_e_total

Fig. 8. 2D polar radiation pattern graph in the projection $Y Z$

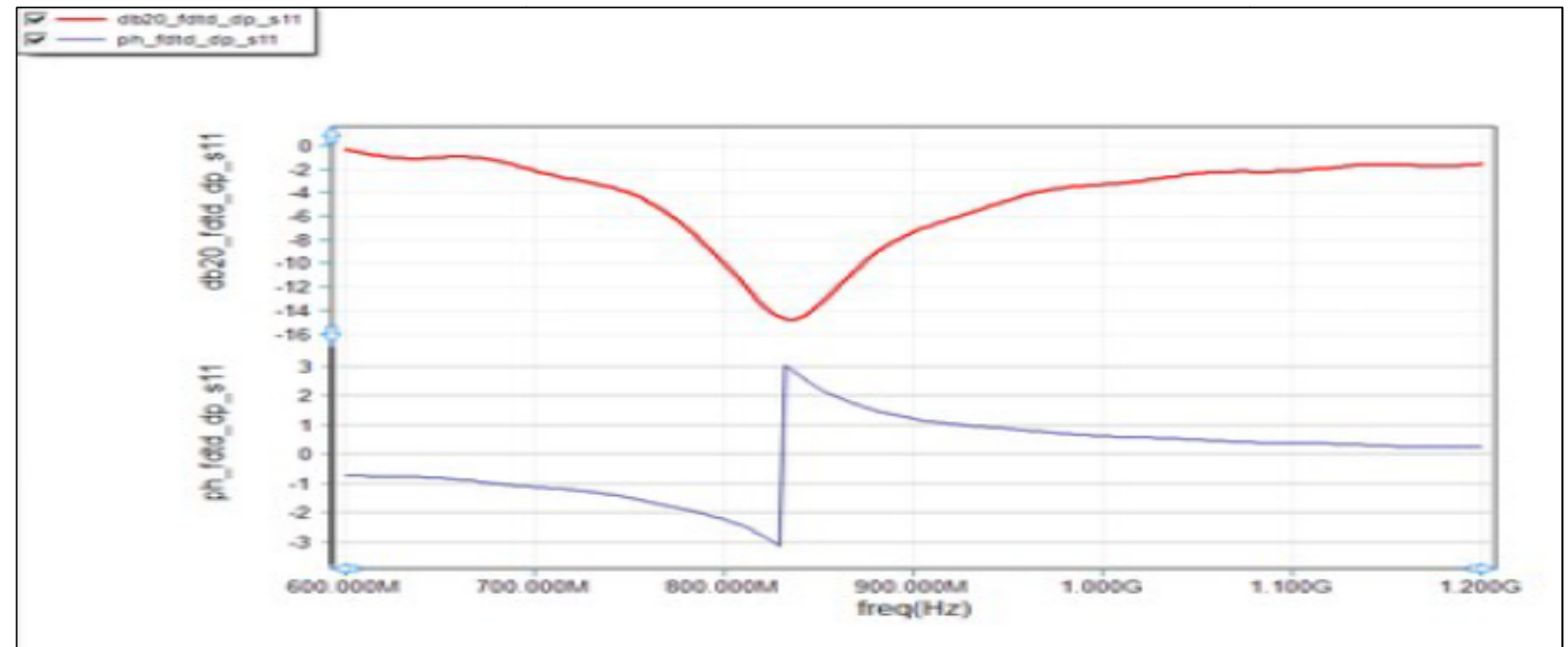

Fig. 9. S11 parameter of the monopole antenna 
In addition, the frequency of the feeding network, the voltage-frequency and the voltage-time are schematically presented below, in Fig. 10-12.

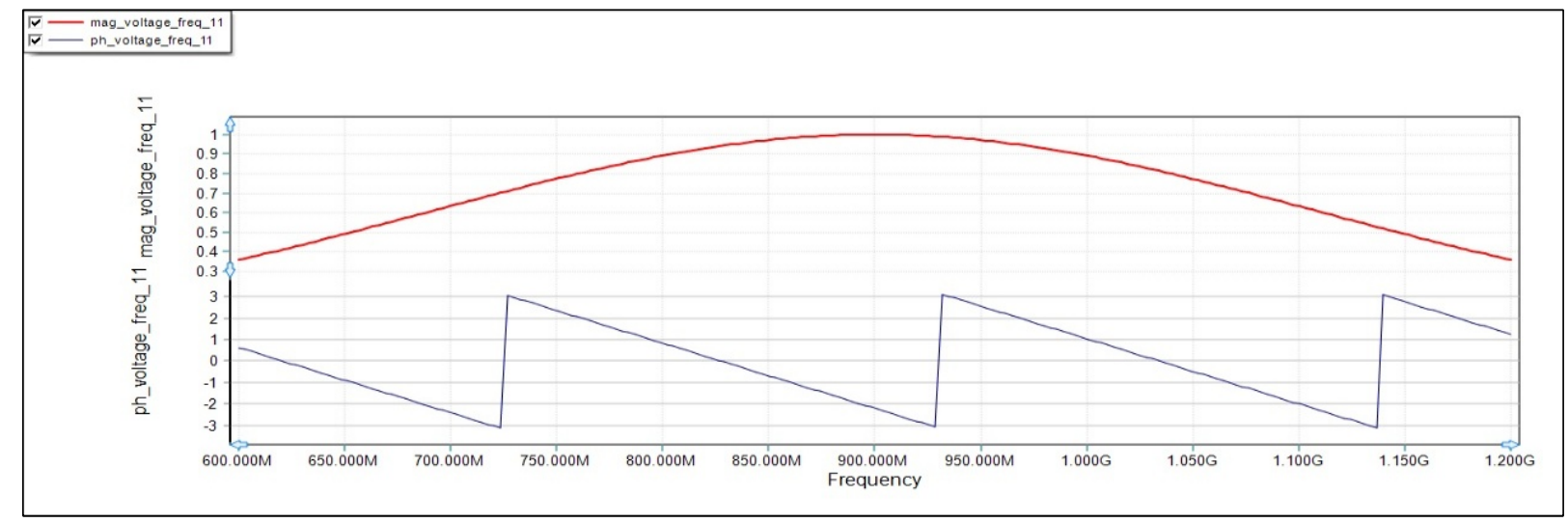

Fig. 10. Frequency of the feeding network of the monopole antenna

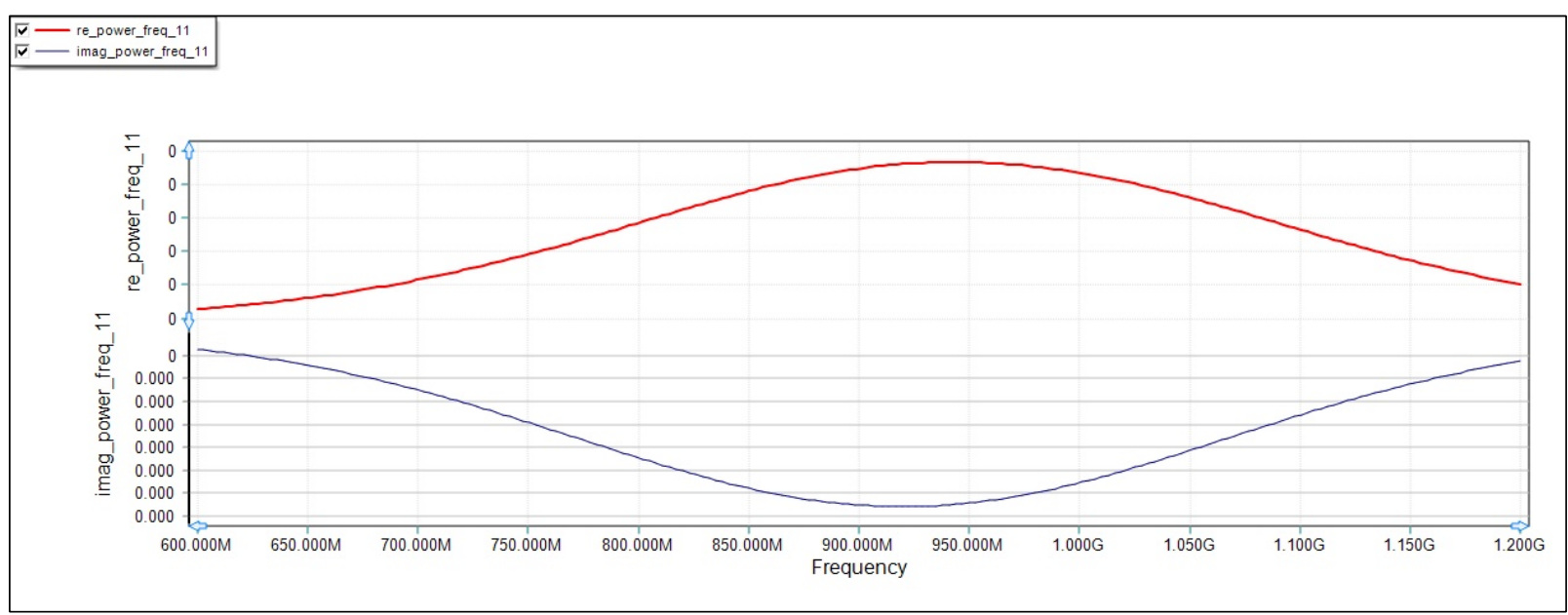

Fig. 11. Voltage frequency of the monopole antenna

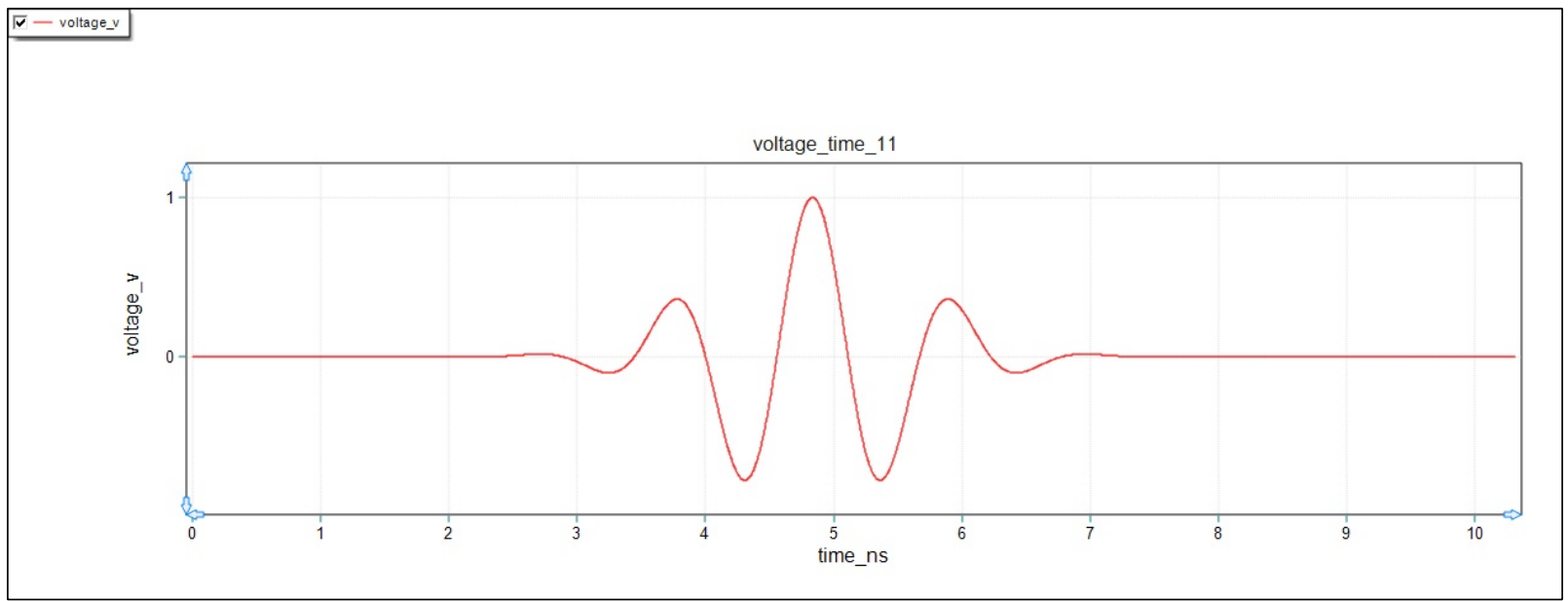

Fig. 12. Voltage time of the monopole antenna

\section{Conclusions}

Any mobile phone radiated an electromagnetic radiations that effect on the human health especially human brain according to the distance of the phone from the head, the type of mobile phones, the type and the position of the antenna that can used in that phones. 
Undoubtedly, an electromagnetic field exceeding certain specified values can have an effect on the organic matter. Experiments on healthy volunteers show that the short-term effect of the background wave radiation of the environment does not have obvious negative consequences. The impact of stronger radiation, which may be harmful, is limited by national and international standards. Debate is currently limited to deciding whether long-term exposure to low-intensity radiation can affect organics and human health. There is as yet no answer to this question.

\title{
References
}

1. Kumar V.B., Gopi V., Jayasree P.V.Y. Evaluation of Electromagnetic Absorption in Human Head from Mobile Phones. IOSR Journal of Engineering (IOSRJEN), 2014, vol. 04, iss. 04, pp. 44-49. Available at: http://www.iosrjen.org/Papers/vol4_issue4\%20(part-6)/H04464449.pdf. DOI: $10.9790 / 3021-04464449$

2. Wiart J. et al. Analysis of the Influence of the Power Control and Discontinuous Transmission on RF Exposure with GSM Mobile Phone. IEEE Trans. Electromagn. Compat., 2000, vol. 42, no. 4, pp. 376-385. DOI: 10.1109/15.902307

3. Bao J.Z. et al. Complex Dielectric Measurements and Analysis of Brain Tissues in the Radio and Microwave Frequencies. IEEE Trans. Microw. Theory Tech., 1997, vol. 45, no. 10, pp. 1730-1741. DOI: $10.1109 / 22.641720$

4. Keshvari J. et al. The Effect of Increase in Dielectric Values on Specific Absorption Rate (SAR) in Eye and Head Tissues Following 900, 1800 and $2450 \mathrm{MHz}$ Radio Frequency (RF) Exposure. Physics in Medical and Biology, 2006, vol. 51, no. 6 pp. 1463-1477. DOI: 10.1088/0031-9155/51/6/007

5. Al-Mously S.I., Abousetta M.M. A Novel Cellular Handset Design for an Enhanced Antenna Performance and a Reduced SAR in the Human Head. International Journal of Antennas and Propagation (IJAP), vol. 2008, Article ID 642572, 10 pages, 2008. DOI:10.1155/2008/642572

6. Chavannes N., Tay R., Nikoloski N., Kuster N. Suitability of FDTD-Based TCAD Tools for RF Design of Mobile Phones. IEEE Antennas and Propagation Magazine, 2003, vol. 45, no. 6, pp. 52-66. DOI: 10.1109/MAP.2003.1282180

7. Beard B.B., Kainz W., Onishi T., Iyama T., Watanabe S., Fujiwara O., Wang J., Bit-Babik G., Faraone A., Wiart J., Christ A., Kuster N., Lee A., Kroeze H., Siegbahn M., Keshvari J., Abrishamkar H., Simon W., Manteuffel D., Nikoloski N. Comparisons of Computed Mobile Phone Induced SAR in the SAM Phantom to that in Anatomically Correct Models of the Human Head. IEEE Transaction on Electromagnetic Compatibility, 2006, vol. 48, no. 2, pp. 397-407. DOI: 10.1109/temc.2006.873870

Received 20 November 2017

\section{ИССЛЕДОВАНИЕ ВОЗДЕЙСТВИЯ ЭЛЕКТРОМАГНИТНОГО ИЗЛУЧЕНИЯ СОТОВОГО ТЕЛЕФОНА НА МОДЕЛЬ ГОЛОВЫ ЧЕЛОВЕКА}

\author{
И.А. Амер, А.О.Дж. Абдалгабар, Н.В. Вдовина \\ Южно-Уральский государственный университет, г. Челябинск, Россия
}

\begin{abstract}
Каждый сотовый телефон излучает электромагнитные волны. В данной работе описано воздействие электромагнитного излучения (ЭМИ) сотового телефона на электрическое и магнитное поле, приводится диаграмма направленности в дальней поля в линейных единицах измерения и в децибелах (дБ) для модели головы человека и для составных компонентов сотового телефона, таких как пластиковый корпус, металлическая основа антенны и металлическая шайба. Исследование модели головы человека под воздействием излучения сотового те-
\end{abstract}


лефона произведено в программе EM.CUBE. Результаты исследований показали возможность использования указанной программы для оценки взаимодействия электромагнитных излучений с биологическими объектами.

Ключевые слова: сотовый телефон, электромагнитное излучение, модель головы человека, диаграмма излучения в дальней зоне, электромагнитное взаимодействие.

Ибрагим Ахмед Амер Ибрагим, аспирант кафедры инфокоммуникационных технологий, Южно-Уральский государственный университет, г. Челябинск; ahmedd20666@gmail.com.

Абдалгабар Омер Джамал Абдалгабар, аспирант кафедры инфокоммуникационных технологий, Южно-Уральский государственный университет, г. Челябинск; omer.jamal1986@ gmail.com.

Вдовина Надежда Владимировна, канд. техн. наук, доцент кафедры инфокоммуникационных технологий, Южно-Уральский государственный университет, г. Челябинск; nadzh@yandex.ru.

Поступила в редакцию 20 ноября 2017 г.

\section{ОБРАЗЕЦ ЦИТИРОВАНИЯ}

Amer, I.A. Investigation of the Effects of Electromagnetic Radiation from a Cell Phone Antenna on a Human Head Model / I.A. Amer, O.J.A. Abdalgabar, N.V. Vdovina // Вестник ЮУрГУ. Серия «Компьютерные технологии, управление, радиоэлектроника». - 2018. - Т. 18, № 1. - С. 163-170. DOI: $10.14529 / \operatorname{ctcr} 180120$

\section{FOR CITATION}

Amer I.A., Abdalgabar O.J.A., Vdovina N.V. Investigation of the Effects of Electromagnetic Radiation from a Cell Phone Antenna on a Human Head Model. Bulletin of the South Ural State University. Ser. Computer Technologies, Automatic Control, Radio Electronics, 2018, vol. 18 , no. 1 , pp. $163-170$. DOI: $10.14529 /$ ctcr 180120 